\title{
Pengenalan dan Pemanfaatan Teknologi Hibrid Membran Terintegrasi untuk Pengolahan Air Bersih
}

\author{
R. Kristoforus Jawa Bendi*1, Fransiska Soejono ${ }^{2}$, Ian Kurniawan ${ }^{3}$, Theresia Sunarni' ${ }^{4}$, Y. Dicka \\ Pratama $^{5}$, Urbanus Dwi Adi Pitoyo6, Maria Rosari Efila7, Romiya Gustira ${ }^{8}$ \\ ${ }^{1}$ Program Studi Informatika, Universitas Katolik Musi Charitas \\ 2Program Studi Manajemen, Universitas Katolik Musi Charitas \\ 3,6Program Studi Teknologi Laboratorium Medis, Universitas Katolik Musi Charitas \\ 4,5 Program Studi Teknik Industri, Universitas Katolik Musi Charitas \\ 7,8Program Studi Pendidikan Guru Sekolah Dasar, Universitas Katolik Musi Charitas \\ *e-mail: $\underline{\text { kristojb@ukmc.ac.id }}^{1}, \underline{\text { fransiska@ukmc.ac.id }}^{2}, \underline{\text { iankurniawan@ukmc.ac.id }}^{3}, \underline{\text { t sunarni@ukmc.ac.id }}^{4}$, \\ $\underline{\text { dicka@ukmc.ac.id }}^{5}$
}

\begin{abstract}
Clean water is one of the problems faced by the Santa Maria Orphanage. To solve this problem, a Community Service Team of the Musi Charitas Catholic University initiated to make a clean water treatment equipment and provide a training for using and maintaining it, and introduced the importance using of clean water for health. The equipment was made by adopting a hybrid membrane technology. It was gived to the manager of the Orphanage and given training to use and maintain it. While the activity evaluation of introducing the importance of clean water for health showed knowledge increasing of participants about $30 \%$.
\end{abstract}

Keywords: orphanage, clean water, hybrid memberane

\begin{abstract}
Abstrak
Salah satu permasalahan yang ditemui di Panti Asuhan Santa Maria adalah ketersediaan air bersih. Hasil analisis laboratorium menunjukkan bahwa air yang digunakan oleh penghuni Panti Asuhan selama ini tidak memenuhi persyaratan air bersih. Untuk mengatasi permasalahan tersebut, Tim Pengabdian kepada Masyarakat Universitas Katolik Musi Charitas berinisiatif membuat alat pengolahan air bersih sekaligus meberikan pelatihan penggunaan dan perawatan alat tersebut, serta memberikan sosialisasi tentang pentingnya menggunakan air bersih bagi kesehatan. Alat pengolahan air bersih tersebut dibuat dengan mengadopsi teknologi membran hibrid. Pada saat pelaksanaan kegiatan, alat tersebut diserahkan kepada pengelola Panti Asuhan dan diberikan pelatihan untuk menggunakan dan merawat alat tersebut. Hasil evaluasi sosialisasi tentang pentingnya air bersih menunjukkan adanya peningkatan pengetahuan peserta sosialisasi sebesar 30\%.
\end{abstract}

Kata kunci: panti asuhan, air bersih, membran hibrid,

\section{PENDAHULUAN}

Kehadiran Panti Asuhan Santa Maria (PA Sanma) bermula dari gagasan seorang pastor yang prihatin dengan masalah ekonomi, sosial, kesehatan dan pendidikan masyarakat di daerah Pasang Surut, Sumatera Selatan (Fransiska, 2017). Pasang Surut merupakan daerah pemukiman transmigran yang didominasi lahan rawa dengan air tanah yang asam dan dan air sungai yang terasa asin (Kelana, 2017). Pada tahun 1985, PA Sanma yang berlokasi di Kecamatan Muara Padang, Kabupaten Banyu Asin, Sumatera Selatan ini mulai menerima anak asuh. Pada awalnya PA Sanma ini dikelola oleh Yayasan Sosial Pansos Bodronoyo, yang kemudian menyerahkannya kepada Keuskupan Agung Palembang. Sejak tahun 2003, PA Sanma kelola oleh Kongregasi SCJ (Congregatio Sacerdotum a Sacro Corde Jesu) Provinsi Indonesia (Wulohering, 2018).

Berawal dari kunjungan pada tahun 2017, sebuah Tim Pengabdian Kepada Masyarakat (Tim PkM) dari Universitas Katolik Musi Charitas (UKMC) kemudian berinisiatif untuk memberikan pendampingan dan membantu menyelesaikan berbagai permasalahan yang dihadapi PA Sanma tersebut melalui skema kegiatan pengabdian kepada masyarakat tahun jamak. Beberapa permasalahan yang telah teridentifikasi antara lain: kualifikasi pengasuh yang kurang 
memadai (Fransiska, 2017; Kelana, 2017), ketersediaan air bersih dan air minum yang kurang memadai (Kelana, 2017), pengembangan kegiatan wirausaha untuk membangkitkan jiwa mandiri anak asuh (Kelana, 2017) sekaligus sebagai sumber pembiayaan (Wulohering, 2018). Selain itu, dalam perbincangan dengan pengelola, tersirat keinginan agar PA Sanma dapat dikenal secara luas. Pengelola juga menyampaikan keinginan untuk melakukan penataan ruang dan lahan di lingkungan PA Sanma yang dapat membangkitkan jiwa kreativitas anak asuh.

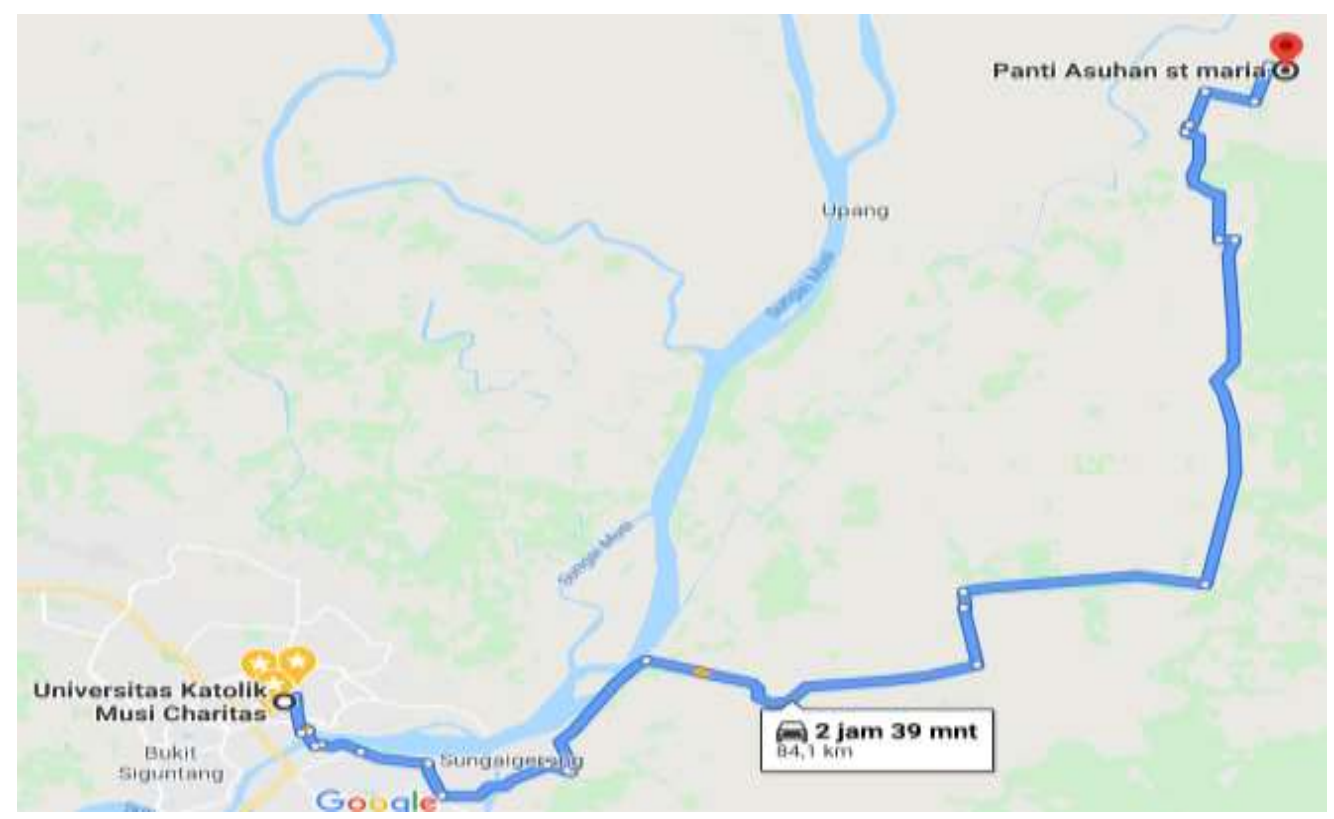

Gambar 1. Lokasi Panti Asuhan Santa Maria

Pada bulan April 2017, kegiatan pertama dari rangkaian kegiatan tahun jamak telah dilakukan oleh Tim PkM. Kegiatan tersebut berupa pembekalan metode pendampingan bagi para pengasuh dan pendampingan pengembangan karakter anak asuh (Riyanto, et al., 2018). Kegiatan lanjutan dilaksanakan pada bulan November 2017 berupa pendampingan pengembangan karakter anak asuh (Soejono F. , et al., 2018; Soejono F. , Riyanto, Widyatusti, \& Kurniawan, 2018) dan pendampingan pengelolaan website (Soejono F. , et al., 2018). Dalam kegiatan berikutnya pada bulan April 2018 Tim PkM memberikan pendampingan terkait laporan keuangan usaha dan desain ruang kreatif (Soejono, et al., 2019). Terkait dengan kegiatan wirausaha yang dijalankan oleh PA Sanma, maka pada bulan Maret 2019, Tim PkM memberikan sosialisasi tentang pentingnya ijin usaha dan ijin edar produk (Soejono, et al., 2019). Dalam kegiatan yang tersebut, Tim PkM mulai melakukan identifikasi awal tentang kualitas air yang digunakan oleh PA Sanma untuk memenuhi kebutuhan air sehari-hari.

Seperti yang telah dikemukakan, PA Sanma berlokasi di daerah Pasang Surut, yang merupakan daerah rawa dengan air payau. Pasang Surut merupakan daerah pemukinan transmigran yang berjarak sekitar 84 kilometer dari Kota Palembang (Gambar 1). Daerah tersebut lebih mudah dicapai melalui jalur sungai. Walaupun tersedia jalur darat, namun kondisi jalannya yang bertanah liat sangat buruk terutama di musim hujan. Untuk memenuhi kebutuhan air harian dan air minum, PA Sanma memanfaatkan air dari sumur bor dan air hujan yang ditampung dalam bak-bak penampungan (Gambar 2) selama musim hujan. Hasil analisis laboratorium pada sampel air yang digunakan oleh PA Sanma menunjukkan kualitas air tersebut kurang memadai untuk digunakan dalam keperluan harian seperti mencuci dan mandi maupun untuk air minum (Soejono, et al., 2019). Pengujian laboratorium pada sampel air, dilakukan dengan teknik analisis fisika dan analisis kimia sesuai dengan Peraturan Menteri Kesehatan Nomor 492/Menkes/Per/IV/2010. Tabel 1 memperlihatkan hasil analisis terhadap sampel air yang 
digunakan. Hasil analisis laboratorium tersebut menunjukkan terdapat beberapa parameter yang melampaui kadar yang diperbolehkan.

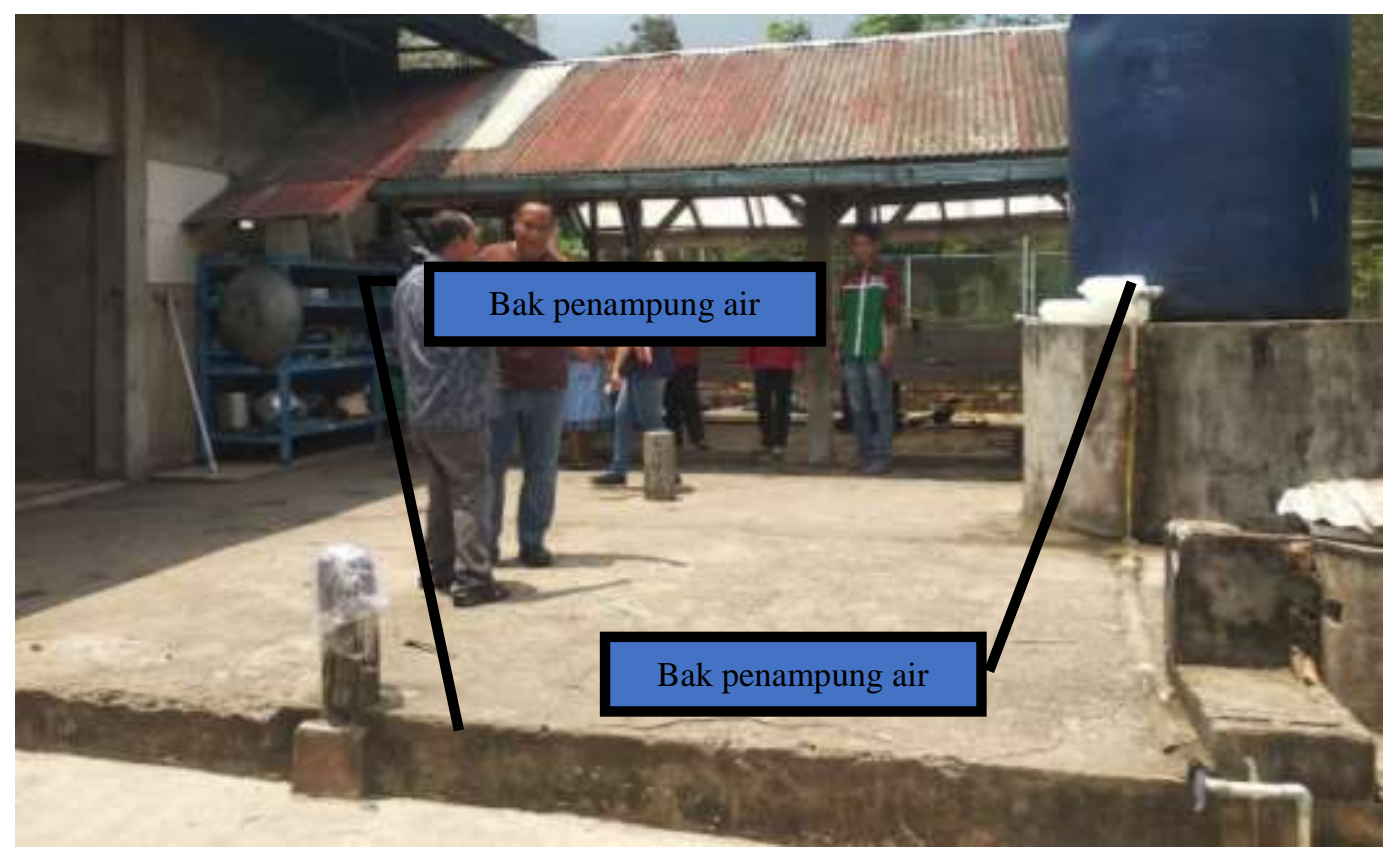

Gambar 2. Bak penampung air

Tabel 1. Hasil analisis air hujan (sampel 1) dan air sumur bor (sampel 2)

\begin{tabular}{cccccc}
\hline $\begin{array}{c}\text { Teknik } \\
\text { analisis }\end{array}$ & Parameter & Satuan & $\begin{array}{c}\text { Konsentrasi } \\
\text { sampel 1 }\end{array}$ & $\begin{array}{c}\text { Konsentrasi } \\
\text { sampel 2 }\end{array}$ & $\begin{array}{c}\text { Kadar yang } \\
\text { diperbolehkan }\end{array}$ \\
\hline Fisika & Bau & berbau & berbau & tidak berbau \\
& Warna & TCU & 18 & 14 & 15 \\
& TDS & $\mathrm{mg} / \mathrm{L}$ & 350 & 200 & 500 \\
& Kekeruhan & $\mathrm{NTU}$ & 10 & 4 & 5 \\
Kimia & Rasa & & berasa & berasa & tidak berasa \\
& $\mathrm{Al}$ & $\mathrm{mg} / \mathrm{L}$ & 0,6 & 0,4 & 0,2 \\
& $\mathrm{Fe}$ & $\mathrm{mg} / \mathrm{L}$ & 1,8 & 2,9 & 0,3 \\
& $\mathrm{Kesadahan}$ & $\mathrm{mg} / \mathrm{L}$ & 375 & 200 & 500 \\
& $\mathrm{pH}$ & & 4,6 & 6 & $6,5-8,5$ \\
& $\mathrm{Cl}$ & $\mathrm{mg} / \mathrm{L}$ & 80 & 40 & 250 \\
& $\mathrm{Mg}$ & $\mathrm{mg} / \mathrm{L}$ & 0,4 & 0,1 & 0,4 \\
& $\mathrm{Zn}$ & $\mathrm{mg} / \mathrm{L}$ & 4,7 & 1 & 3 \\
& $\mathrm{NH}$ & $\mathrm{mg} / \mathrm{L}$ & 1 & 1 & 1,5 \\
\hline
\end{tabular}

Kondisi serupa tentang kebutuhan air bersih juga diungkapkan oleh Earnestly et al (2019) dalam kegiatan pengabdian kepada masyarakat di daerah Pasie Nan Tigo, Padang. Untuk mengatasi kondisi tersebut, Earnestly et al memberikan pendampingan dalam membuat alat penjernih air. Penggunaan air hujan untuk memenuhi kebutuhan air minum dengan menggunakan alat penyaring air juga pernah dilakukan oleh Wahyuni, Sari, \& Afidah (2017) dalam kegiatan pengabdian kepada masyarakat di daerah Mengkapan, Riau. Oleh karena itu Tim PkM berinisiatif untuk: (1) menyediakan bagi Panti Asuhan alat pengolahan air bersih dengan memanfaatkan teknologi hybrid membrane, (2) memberikan pelatihan tentang penggunaan dan 
perawatan alat penyaring air tersebut, (3) membekali penghuni Panti Asuhan dengan pengetahuan tentang pentingnya penggunaan air bersih untuk kesehatan.

\section{METODE}

Pelaksanaan kegiatan dilakukan dalam tiga tahap. Pada tahap pertama, Tim PkM membuat alat pengolahan air bersih. Teknologi yang digunakan dalam pembuatan alat ini adalah teknologi filtrasi air dengan menggunakan membran hibrid terintegrasi. Membran hibrid adalah proses perancangan filtrasi air dengan menggunakan 2 jenis/tipe membran atau lebih. Alat yang dibuat ini menggunakan membran hibrid terintegrasi dengan 2 buah tipe membran yang dilengkapi dengan peralatan pendukung seperti membrane housing dan pipa air. Kapasitas pengolahan air dapat memproses dalam skala kecil rumah tangga sebesar 1 gallon/15 menit atau 20 liter/15 menit.

Pada tahap kedua, Tim PkM memberikan sosialisasi tentang pentingnya air bersih bagi kesehatan. Kegiatan ini dilaksanakan di PA Sanma yang diikuti oleh seluruh pengelola sebagai peserta sosialisasi. Materi sosialisasi mencakup (1) sumber-sumber air yang dapat digunakan, (2) kualitas air bersih, (3) kandungan berbahaya dalam air yang tercemar serta akibatnya bagi kesehatan, (4) berbagai teknik pengolahan air bersih, dan (5) pengenalan teknologi membran untuk pengolahan air bersih. Bentuk kegiatan sosialisasi berupa ceramah dan diskusi. Evaluasi kegiatan dilakukan dengan prates diawal kegiatan dan postes diakhir kegiatan.

Tahap ketiga, dilakukan pelatihan penggunaan dan perawatan alat pengolahan air yang telah dibuat pada tahap pertama. Kegiatan ini diawali dengan pengenalan alat dan komponen-komponen membran. Setelah itu dilanjutkan dengan praktek penggunaan alat pengolahan air tersebut. Kegiatan pada tahap ini diakhiri dengan penjelasan tentang cara perawatan komponen-komponen membran.

\section{HASIL DAN PEMBAHASAN}

\section{Pembuatan Alat Pengolahan Air Bersih}

Pengolahan air sangat tergantung dari karakteristik atau kualitas air baku yang digunakan. Pencemaran-pencemaran yang harus diperhatikan pada kebanyakan persediaan air adalah bakteri pathogen, kekeruhan dan bahan-bahan terapung, warna, rasa dan bau, dan senyawa-senyawa organik. Membran filtrasi dapat digunakan sebagai teknologi alternative pemurnian air selain flokulasi, teknik pemurnian sedimen, adsorpsi, filter pasir dan filter karbonaktif, penukar ion, ekstraksi, dan distilasi (Watanabe \& Kimura, 2011).

Konsep kinerja membran filtrasi dapat terlihat pada Gambar 3, bahwa hanya partikel kontaminan yang ukurannya lebih kecil dari pori membran yang bisa melewati membran (Madsen, 2014). Berdasarkan ukuran diameter porinya membran terklasifikasi atas (1) mikrofiltrasi yang mampu menyaring partikel berukuran 0,1 - $10 \mu \mathrm{m}$, (2) ultrafiltrasi yang mampu menyaring partikel berukuran 0,001 - 0,1 $\mu \mathrm{m},(3)$ reverse osmosis yang mampu menyaring partikel berukuran 0,0001-0,001 $\mu \mathrm{m}$, dan (4) nanofiltrasi untuk mengurangi kesadahan, reduksi bakteri dan virus serta zat organik (Kurniawan \& Mariadi, 2016). Sedangkan berdasarkan modul atau bentuknya membran terklasifikasi menjadi (1) hollow fibre, (2) turbular device, (3) flat plate modul, dan (4) spiral wound. 


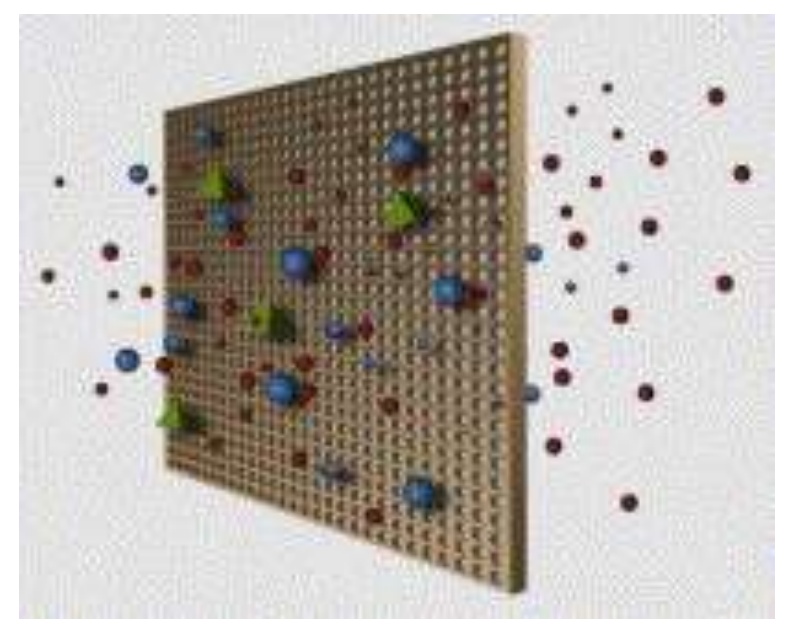

Gambar 3. Proses kerja membran

Membran hibrid terintegrasi merupakan suatu proses pengolahan air dengan membran dalam suatu instalasi melalui penggabungan satu atau lebih proses membran dengan atau tanpa proses konvensional untuk meningkatkan kinerja tergantung dari karakteristik umpan dan produk yang akan dihasilkan (Grennlee, Lawler, Freeman, Marrot, \& Moulin, 2009). Sistem membran hibrid terintegrasi juga dapat mengurangi biaya operasional dan pencemaran lingkungan serta membuat keseluruhan proses menjadi efisien.

Rancangan membran hibrid terintegrasi yang dibuat untuk PA Sanma menggunakan gabungan dua buah membran berskala rumah tangga dengan kapasitas pengolahan 1 gallon/15 menit atau setara dengan 20 liter/15 menit. Membran pertama dengan jenis mikrofiltrasi menggunakan konsep hollow fibre. Sedangkan membran kedua bertipe ultrafiltrasi menggunakan keramik dengan konsep turbular device. Peralatan pendukung membran dilengkapi dengan housing, pipa PVC dan dua tahap pretreatment menggunakan karbon aktif dan silikia untuk menghasilkan kinerja filtrasi membran yang maksimal. Pompa dengan tekanan maksimal 230 psi sebagai komponen pengatur tekanan aliran air juga digunakan sebagai pendukung membran hibrid. Dalam proses pengolahannya, air umpan/baku dimasukkan ke dalam pipa menggunakan aliran pompa untuk mencapai membrane housing .

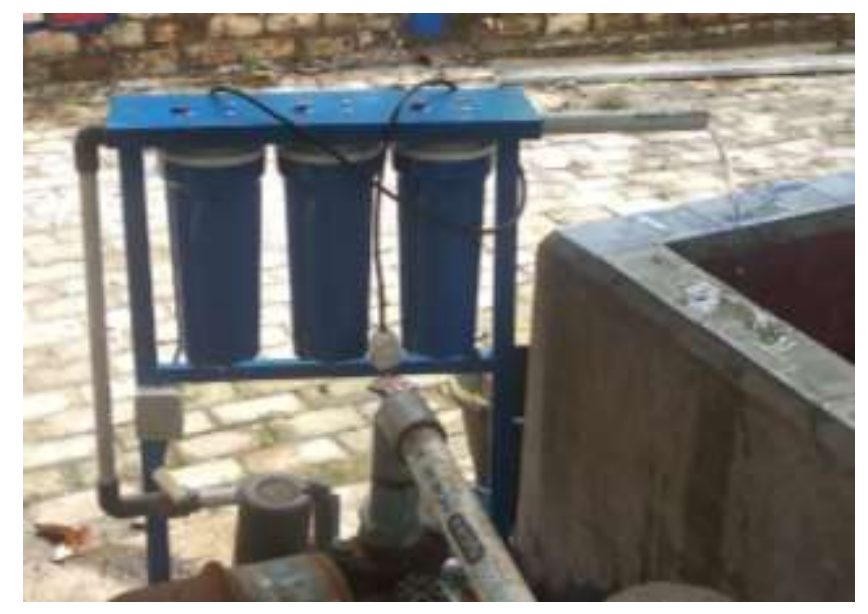

Gambar 4. Tampak membran hibrid terintegrasi yang dibuat

\section{Kegiatan Sosialisasi Pentingnya Air Bersih}

Kegiatan sosialisasi dilaksanakan di PA Sanma pada tanggal 28 September 2019. Perjalanan menuju lokasi kegiatan ditempuh dalam waktu \pm 2 jam melalui jalur sungai dengan 
menggunakan speedboat. Tim PkM berangkat pukul 08.30 dan tiba di lokasi kegiatan pada pukul 10.30. Kegiatan diawali dengan diskusi singkat bersama kepala PA Sanma sembari Tim PkM bersitirahat sejenak dan menyiapkan peralatan. Setelah itu, Tim PkM diajak untuk meninjau tempat-tempat penampungan air yang digunakan selama ini (Gambar 2).

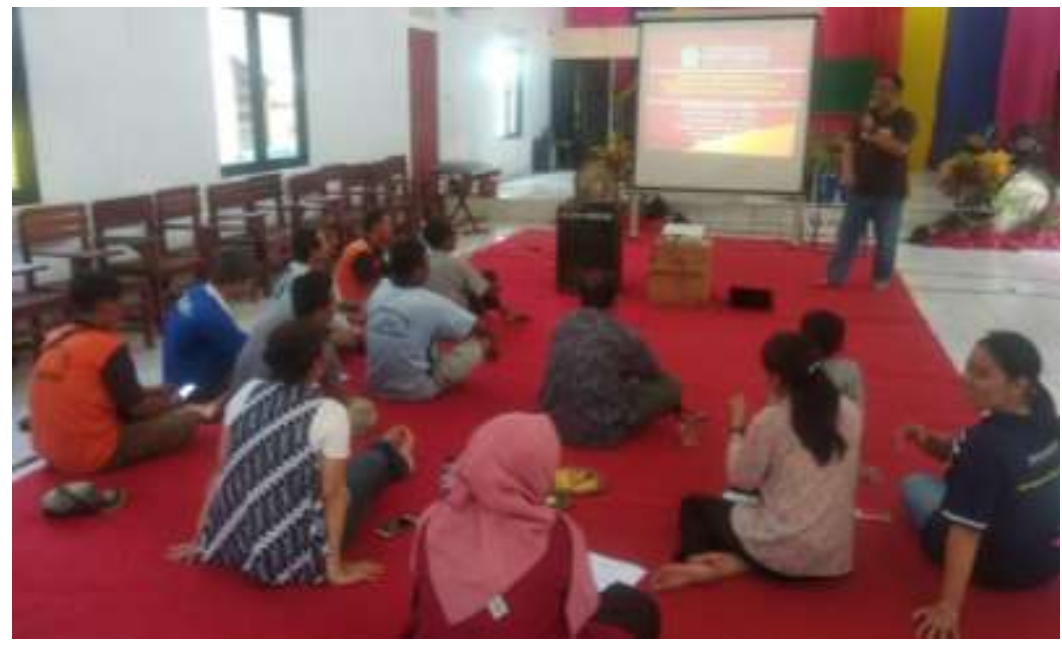

Gambar 5. Suasana kegiatan sosialisasi pentingnya air bersih

Kegiatan sosialisasi (Gambar 5) diikuti sembilan peserta yang merupakan pegawai yang pekerjaannya terkait langsung dengan ketersediaan air di lingkaungan PA Sanma. Harapannya Sembilan peserta tersebut memahami pentingnya air bersih serta memahami penggunaan dan pemeliharaan teknologi filtrasi air karena mereka nantinya yang akan menjadi operator sekaligus teknisi pemeliharaan alat tersebut. Kegiatan sosialisasi dilakukan dalam bentuk ceramah dan diskusi. Untuk mengetahui pemahaman peserta, sebelum kegiatan dimulai setiap peserta diberikan prates dan postes diakhir kegiatan. Hasil prates dan postes (Tabel 2) menunjukkan adanya peningkatan pengetahuan dan pemahaman peserta tentang pentingnya air bersih.

Tabel 2. Hasil prates dan postes

\begin{tabular}{|c|c|c|c|c|c|c|}
\hline \multirow{2}{*}{ No. } & \multirow{2}{*}{ Pernyataan } & \multicolumn{2}{|c|}{ Prates } & \multicolumn{2}{|c|}{ Postes } & \multirow{2}{*}{ Selisih } \\
\hline & & skor & persentase & skor & Persentase & \\
\hline 1 & Sumber air & 7 & $87,50 \%$ & 7 & $87,50 \%$ & $0 \%$ \\
\hline 2 & Penyebab terjadinya hujan & 6 & $75 \%$ & 7 & $87,50 \%$ & $13 \%$ \\
\hline 3 & Komponen kualitas air & 4 & $50 \%$ & 6 & $75 \%$ & $25 \%$ \\
\hline 4 & $\begin{array}{l}\text { Kandungan berbahaya dalam air } \\
\text { tercemar }\end{array}$ & 5 & $62,50 \%$ & 8 & $100 \%$ & $38 \%$ \\
\hline 5 & $\begin{array}{l}\text { Penyakit akibat konsumsi air } \\
\text { tercemar }\end{array}$ & 5 & $62,50 \%$ & 8 & $100 \%$ & $38 \%$ \\
\hline 6 & Pengolahan air secara sederhana & 5 & $62,50 \%$ & 7 & $87,50 \%$ & $25 \%$ \\
\hline 7 & Pengolahan air teknologi terkini & 4 & $50 \%$ & 7 & $87,50 \%$ & $38 \%$ \\
\hline 8 & Perangkat alat filtrasi membran & 5 & $62,50 \%$ & 7 & $87,50 \%$ & $25 \%$ \\
\hline 9 & $\begin{array}{l}\text { Indikasi penurunan kinerja } \\
\text { membran }\end{array}$ & 4 & $50 \%$ & 8 & $100 \%$ & $50 \%$ \\
\hline 10 & Perawatan alat filtrasi membran & 4 & $50 \%$ & 8 & $100 \%$ & $50 \%$ \\
\hline & Rerata & 4,9 & $61 \%$ & 7,3 & $91 \%$ & $30 \%$ \\
\hline
\end{tabular}

Secara keseluruhan terdapat peningkatan pengetahuan dan pemahanan peserta sebesar $30 \%$. Jika ditinjau dari setiap pernyataan, terlihat bahwa pengetahuan peserta tentang kandungan berbahaya dalam air dan dampaknya bagi kesehatan, serta pengetahuan tentang teknologi 
pengolahan air meningkat sebesar 38\%. Pada penyataan mengenai kulitas air dan pengetahuan tentang teknologi mebran mengalami peningkatan sebesar 25\%. Sedangkan penytaan tentang kinerja dan perawatan alat pengolahan berbasis teknologi membran terdapat peningkatan 50\%. Hal ini menunjukkan bahwa kegiatan sosialisasi ini memberikan dampak perubahan pengetahuan peserta.

\section{Pelatihan Penggunaan dan Perawatan Alat}

Setelah kegiatan sosialisasi berakhir, dilanjutkan dengan pelatihan penggunaan alat pengolahan air bersih tersebut (Gambar 6). Kegiatan ini diawali dengan pengenalan komponenkomponen membran hibrid terintegrasi dan dilanjutkan dengan penjelasan mengenai cara perawatannya. Setelah itu alat diujicobakan secara langsung oleh operator (Gambar 7).

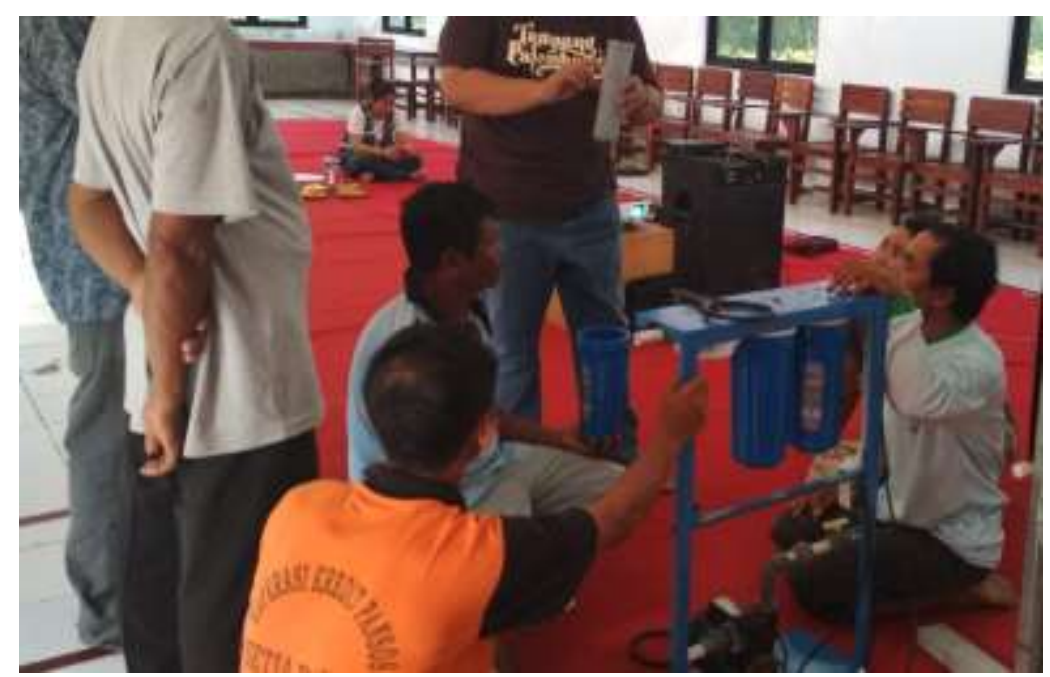

Gambar 6. Suasana pelatihan penggunaan alat

Dalam diskusi selanjutnya terungkap bahwa PA Sanma sudah memiliki alat pengolahan air berbasis teknologi membran yang berjenis nanofiltrasi. Operator atau teknisi perangkat tersebut dapat mengoperasikannya namun tidak mengetahui cara perawatannya. Dengan adaanya kegiatan ini, mereka menyatakan bahwa mereka mendapatkan pengetahuan tentang cara perawatan membran. Kepala PA Sanma juga mengungkapkan bahwa mereka mendapatkan donasi alat pengolahan air berteknologi membran yang bertipe reverse osmosis (Gambar 8). Namun karena keterbatasan pengetahuan tentang penggunaan dan pemeliharaannya, alat tersebut tidak pernah digunakan dan hanya disimpan dalam gudang.

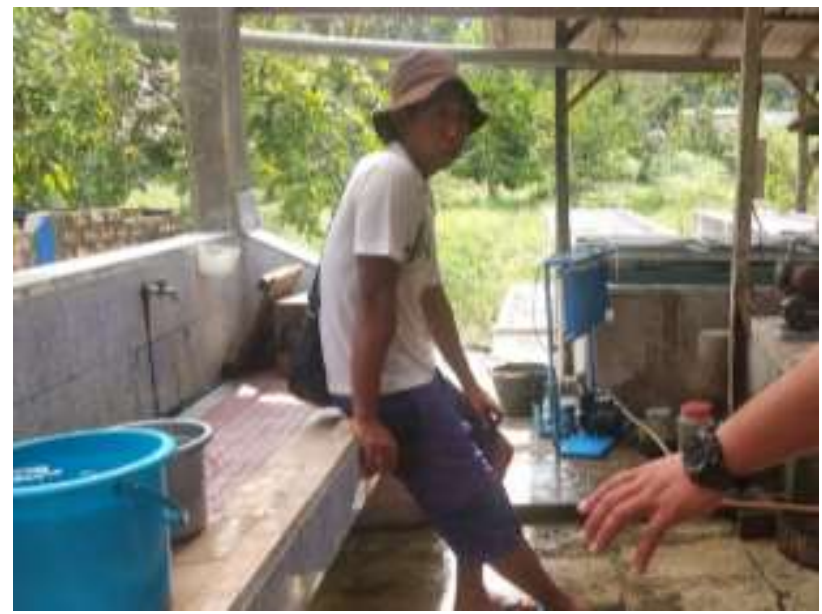

Gambar 7. Uji coba alat oleh operator 


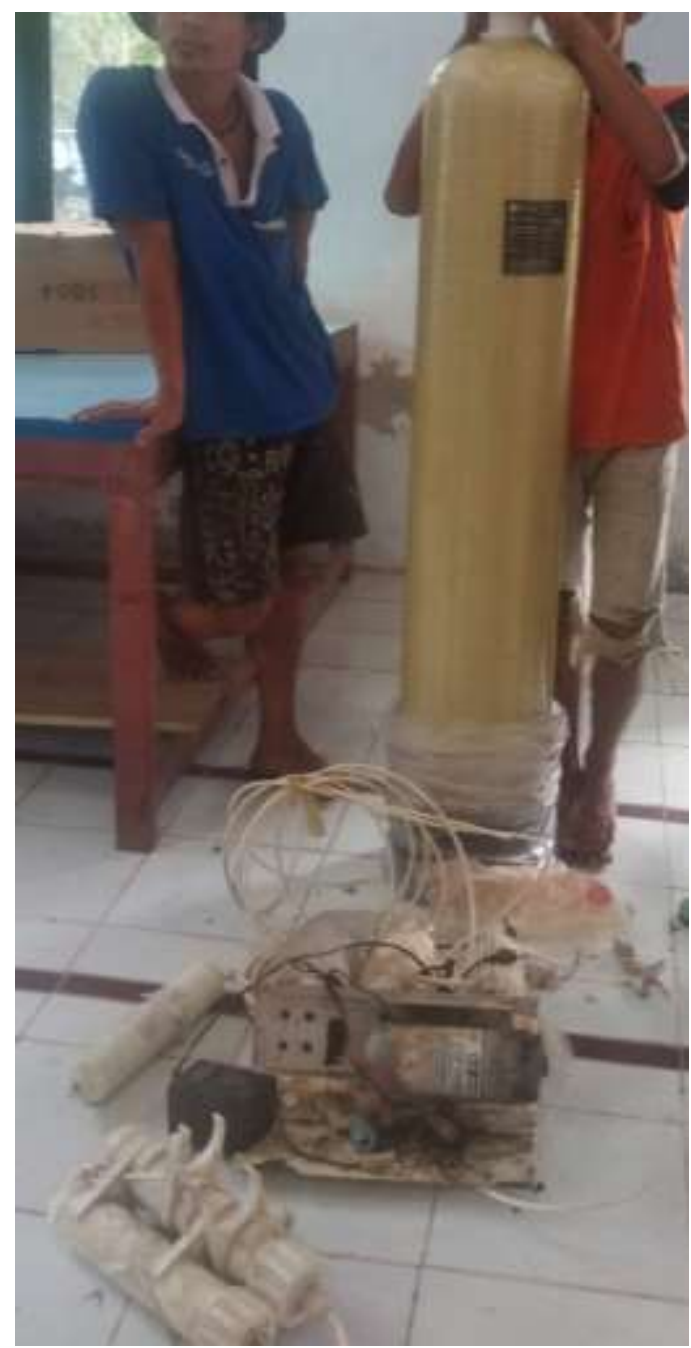

Gambar 8. Membran reverse osmosis

Untuk mengetahui manfaat dan dampak kegiatan ini bagi peserta, Tim PkM memberikan kuesioner mengenai tanggapan peserta atas pelaksanaan kegiatan. Secara umum peserta menilai kegiatan tersebut sangat baik (Tabel 3) dengan rerata skor 4,47 dari 5. Peserta juga menyatakan bahwa kegiatan ini sangat bermanfaat (skor 4,71), materi kegiatan yang jelas dan bentuk kegiatan yang menarik. Selanjutnya peserta juga mengharapkan adanya kegiatan lanjutan dengan topik yang berbeda.

Tabel 3. Tanggapan atas pelaksanaan kegiatan

\begin{tabular}{clc}
\hline No. & \multicolumn{1}{c}{ Pernyataan } & Rerata skor \\
\hline 1 & Topik kegiatan menarik. & 4,29 \\
2 & Bahan/materi kegiatan menarik & 4,29 \\
3 & Penyampaian materi/bahan jelas & 4,57 \\
4 & Bentuk kegiatan ini secara umum menarik & 4,57 \\
5 & Kegiatan ini sangat bermanfaat & 4,71 \\
6 & Kegiatan berikutnya dengan topik berbeda sangat diharapkan & 4,43 \\
\hline & Rerata & 4,47 \\
\hline
\end{tabular}




\section{KESIMPULAN}

Kesimpulan yang dapat diambil dari kegiatan tersebut adalah sebagai berikut.

1. Kegiatan dengan topik ini dirasakan sangat bermanfaat bagi mitra.

2. Sebagian besar peserta mengalami peningkatan pengetahuan terkait materi pelatihan tersebut.

3. Peserta menyadari pentingnya filtrasi air sebelum digunakan untuk kebutuhan masak makanan dan minuman.

4. Peserta menyadari kebutuhan akan keterampilan perakitan, penggunaan dan perawatan alat filtrasi air yang sebenarnya sudah mereka miliki.

\section{UCAPAN TERIMA KASIH}

Penulis mengucapkan terima kasih kepada Universitas Katolik Musi Charitas yang telah memberi dukungan finansial terhadap kegiatan pengabdian ini. Terima kasih juga teruntuk pengelola Panti Asuhan Santa Maria yang telah memberikan kesempatan kepada penulis untuk melaksanakan kegiatan pengabdian tahun jamak.

\section{DAFTAR PUSTAKA}

Earnestly, F., Suryani, Firdaus, \& Yermadona, H. (2019). Penjernihan Air di RT 001/ RW 013 Kelurahan Pasie Nan Tigo. Dinamisia, 3(Special Issue), 101-109.

Fransiska, M. (2017, Agustus 3). Kasih Maria Menyertai 30 Tahun Panti Asuhan St Maria Pasang Surut Banyuasin. Retrieved from Hidup Katolik: https://majalah.hidupkatolik.com/ 2017/08/03/6444/kasih-maria-menyertai-30-tahun-panti-asuhan-st-maria-pasang-surutbanyuasin/

Grennlee, L. F., Lawler, D. F., Freeman, B. D., Marrot, B., \& Moulin, P. (2009). Reverse osmosis desalination: Water sources, technology, and today's challenges. Water Research, 43(9), 23172348.

Kelana, T. J. (2017, Oktober 29). Panti Asuhan St. Maria Pasang Surut Sumsel: Membangun Anak Jadi Kreatif dan Penuh Harapan. Retrieved from Sesawi: Portal Berita Katolik Indonesia: https://www.sesawi.net/panti-asuhan-st-maria-pasang-surut-sumsel-membangun-anakjadi-kreatif-dan-penuh-harapan/

Kurniawan, I., \& Mariadi, P. D. (2016). Review: Profil Hybrid Membrane Dalam Proses Reduksi Air Limbah. Konversi, 5(1), 1-10.

Madsen, H. T. (2014). Membrane Filtration in Water Treatment - Removal of Micropollutants. In Chemistry of Advanced Environmental Purification Processes of Water Fundamentals and Applications (pp. 199-248). Elsevier.

Riyanto, A., Soejono, F., Yeniyati, P., Sunarni, T., Mustika, S. W., \& Halim, S. (2018). Pengelolaan Panti Asuhan SanMa Pasang Surut: Metode Pendampingan Anak. Jurnal Abdimas Musi Charitas, 2(1), 12-16.

Soejono, F., Kurniawan, I., Sunarni, T., Pratama, Y. D., Bendi, R. K., Pitoyo, U. A., . . Wiguna, V. C. (2019). Pentingnya P-IRT dan Identifikasi Kandungan Air Di Panti Asuhan Santa Maria Pasang Surut. Jurnal Terapan Abdimas, 4(2), 160-165.

Soejono, F., Mustika, S. W., Hermawan, L., Sunarni, T., Anggraeni, D. W., Taslim, J., . . Oemar, R. (2019). Pengelolaan Panti Asuhan Santa Maria: Laporan Keuangan Usaha dan Desain Ruang Kreatif. Jurnal Terapan Abdimas, 4(1), 1-6.

Soejono, F., Riyanto, A., Bendi, R. K., Widyastuti, T., Sunarni, T., Akbar, R., ... Supriyanto, Y. (2018). Peningkatan Manajemen Panti Asuhan SanMa: Pengembangan Karakter Anak dan Pembuatan Website. Asawika, 2(2), 1-6.

Soejono, F., Riyanto, A., Widyatusti, T., \& Kurniawan, I. (2018). Management Of Santa Maria Orphanage: Children Accompaniment. APTIK International Conference on Poverty and Environment. 
Wahyuni, S., Sari, M., \& Afidah, M. (2017). Sosialisasi dan Pelatihan Teknik Penyaringan Air di Desa Mengkapan, Siak. Dinamisia, 1(1), 100-105.

Watanabe, Y., \& Kimura, K. (2011). Membrane Filtration in Water and Wastewater Treatment. In Treatise on Water Science (pp. 23-61). Elsevier Science.

Wulohering, H. (2018, November 28). Panti Asuhan Santa Maria: Tangan Di Atas Meraih Mimpi. Retrieved from Hidup Katolik: https://www.hidupkatolik.com/2018/11/28/29538/ pantiasuhan-santa-maria-tangan-di-atas-meraih-mimpi/ 